\title{
Self-pollination of the orchid Cycnoches haagii from Brazilian Cerrado results in albino phenotype seedlings
}

\author{
Vespasiano Borges de Paiva Neto ${ }^{1 *}$ (D), Mateus de Aguiar Torrezan ${ }^{1}$ (D), Manoela Aparecida Vieira da Silva ${ }^{2}$ (D), \\ Daly Roxana Castro Padilha ${ }^{3}$ (D), Jerônimo Constantino Borel ${ }^{1}$ (D), Monica Cristina Rezende Zuffo-Borges ${ }^{1}$ (D) \\ ${ }^{1}$ Universidade Federal do Vale do São Francisco, Campus de Ciências Agrárias, Colegiado de Engenharia Agronômica, Petrolina-PE, Brazil. \\ ${ }^{2}$ Universidade Federal de Mato Grosso do Sul, Campus de Chapadão do Sul, Chapadão do Sul-MS, Brazil. \\ ${ }^{3}$ Universidade Federal de Mato Grosso do Sul, Campus do Pantanal, Corumbá-MS, Brazil.
}

\begin{abstract}
Cycnoches haagii Barb. Rodr. is an epiphytic orchid very targeted by collectors, but no reference was found in the literature about its reproductive biology. Thus, the purpose of this study was to obtain initial information regarding pollination types and its influence on seed viability of this native orchid of the Brazilian Cerrado, in order to enable future propagation and preservation programs. Pollination among flowers of the same plant (geitonogamy) or different plants (xenogamy) were carried out. Seeds extracted from the capsules were sown in B\&G medium, with full and half strength. Seeds from geitonogamic resulted in $25 \%$ of albino protocorms and consequently in albino seedlings. This phenomenon did not occur in seedlings derived from xenogamic pollination. Pigment analysis showed that even the albino seedlings presented chlorophylls and carotenoids, however, in significantly minor concentrations, $16 \%$ and $37 \%$ respectively, in relation to green seedlings. Geitonogamic and xenogamic pollinations resulted in $C$. haagii viable seeds with high germination percentage (90\%) under in vitro conditions. The germination of seeds from xenogamic pollination resulted in chlorophyll or normal seedlings only, and can be recommended at conservation programs. On the other hand, although geitonogamic pollination should be avoided at conservation programs of this orchid species as it leads to albino seedlings, it showed a very interesting system to obtain seedlings with this phenotype, an interesting plant material to future investigation.
\end{abstract}

Keywords: albinism, geitonogamy, germination, orchid, plant pigments.

\section{Resumo}

Autopolinização de Cycnoches haagii, orquídea nativa do Cerrado Brasileiro, resulta em plântulas fenotipicamente albinas Cycnoches haagii é uma orquídea epífita alvo de muitos coletores, mas nenhuma referência foi encontrada na literatura sobre sua biologia reprodutiva. Assim, o objetivo deste estudo foi obter informações preliminares sobre os tipos de polinização e sua influência na viabilidade das sementes desta orquídea nativa do Cerrado brasileiro, a fim de viabilizar futuros programas de multiplicação e preservação. Foram realizadas polinizações entre flores da mesma planta (geitonogamia) ou plantas diferentes (xenogamia). As sementes obtidas das cápsulas foram semeadas em meio B\&G, com concentração total e parcial de sais. Sementes de geitonogamia resultaram em $25 \%$ dos protocormos albinos e consequentemente em plântulas albinas. Este fenômeno não ocorreu em sementes oriundas de polinização xenogâmica. A análise de pigmentos mostrou que mesmo as plântulas albinas apresentaram clorofilas e carotenoides, porém em concentrações significativamente menores, $16 \%$ e $37 \%$ respectivamente, em relação às plântulas pigmentadas. A polinização geitonogâmica deve ser evitada em programas de propagação da orquídea $C$. haagii devido à origem de plântulas albinas. Além disso, a polinização xenogâmica mostrou-se um método muito interessante para a obtenção de mudas com fenótipo albino, material vegetal muito intrigante para futuras investigações.

Palavras-chave: albinismo, geitonogamia, germinação, orquídea, pigmentos vegetais.

\section{Introduction}

Orchidaceae is one of the largest plant families, containing more than 25,000 species in the entire world (Chase et al., 2015), but unfortunately, it is also among the most threatened of all flowering plants (Huang et al., 2018).
Cycnoches haagii Barb. Rodr. is an epiphytic and not endemic orchid native to the Cerrado Domain, being found in different vegetation formations in the Brazilian states of Amazonas, Pará, Rondônia, Goiás and Mato Grosso (Barros et al., 2015). In the state of Mato Grosso do Sul, the species was reported in the municipality of Costa

*Corresponding Author: vespasiano.paiva@univasf.edu.br 
Rica (Barros et al., 2018). As it is a species with high ornamental potential (Torrezan et al., 2018), and given the beauty and delightful smell of the flowers, as well as the magnitude of the vegetative structures, these authors affirm that studies on the propagation process of this orchid are essential, not only to improve the production process making it economically viable, but also to preserve, promoting the perpetuation of the species, thus reducing the risk of extinction.

In vitro propagation has been proven to be effective in mass multiplication of a number of native orchids with different focus, as species conservation (Silva et al., 2017; Hunhoff et al., 2018; Bezerra et al., 2019), commercial purposes (Balilashaki et al., 2015) or both goals (Mercado and Contreras, 2017; Utami and Hariyanto, 2019). According to Rasmussen et al. (2015), in any conservation or restoration program for native orchid populations, a definition of factors that limit seed germination and seedling establishment must be investigated.

Currently, there is only one study on in vitro germination of $C$. haagii, using seeds extracted from capsules collected in situ (Torrezan et al., 2018). Genetic compatibility and germination information are required to guide comprehensive management strategies for species successful conservation, as proposed by Paiva Neto et al. (2015) to the orchid Bletia catenulata, which can generate capsules and viable seeds by self or cross-pollination. In this aspect, researches involving orchid reproductive biology are essential to start a multiplication process or a breeding system of a given species of interest.

Most orchids are self-compatible. However, spontaneous self-pollination tends to be avoided by the presence of some floral mechanisms (Catling and Catling, 1991; Smidt et al., 2006). Although the number of studies on pollination biology and reproduction involving Brazilian orchids has increased in recent years, there are still few researches taking into account the importance and the number of native Orchidaceae species (Mickeliunas et al., 2006).

Asymbiotic seed germination has also been used for the multiplication of commercially important orchids, and it has shown to be an effective tool for the orchids mass production for conservation and reintroduction purposes (Stewart and Kane, 2006; Johnson and Kane, 2012; Wu et al., 2014). However, a few researchers have reported the appearance of albino seedling during the germination process, but in different plant species, as Arabidopsis thaliana (Tada et al., 2014) and Delonix regia (Silva et al., 2020). Albinism can be associated with several genetic or biochemical factors, including the incompatibility between nuclear and plastid genomes, deletions in plastidial DNA, genetic mutations in nuclear loci, meiotic abnormalities, or even the incomplete development of chloroplasts, all of which result in dramatic changes in chloroplast biogenesis (Kumari et al., 2009).

Thus, the purpose of this study was to obtain initial information regarding pollination types and its influence on seed viability of the orchid $C$. haagii, a Brazilian Cerrado native species, in order to enable future preservation and multiplication programs.

\section{Material and Methods}

Three adult plants of $C$. haagii collected at a pasture area (18 32'25.52”S and 53'9'27.03”W) near Costa Rica city, Mato Grosso do Sul, Brazil, supported by SISBIO 225702 authorization, were used in the pollination experiments. These matrices plants were cultivated in plastic pots $(2 \mathrm{~L})$, using Plantmax ${ }^{\circledR}$ - HT as substrate, and maintained in a greenhouse with daily irrigation and used in the pollination experiments. For species identification procedures, exsiccateswere prepared and deposited in the herbarium of the Instituto de Botânica (SP), São Paulo State, Brazil.

The reproductive biology experiments were carried out by manual pollination of at least three female flowers that received pollinia from male flowers of the same plant (geitonogamy) or from male flowers of another plant (xenogamy), respectively. In both related cases, pollinia were dislodged from the gynostemium by applying slight upward pressure to the bottom of the anther cap and after removal, pollinium was gently transferred into the stigmatic surface. Manually pollinated flowers were closely monitored for capsule development and capsule maturity.

After fruits were ripened, in vitro seed germination was carried out. Fruits were sterilized for twenty minutes in a solution of sodium hypochlorite ( $2 \%$ active Chlorine), followed by five minutes in $70 \%$ ethanol solution, and finally rinsed three times in sterile distilled water, as proposed by Paiva Neto et al. (2015). Seeds of each pollination type

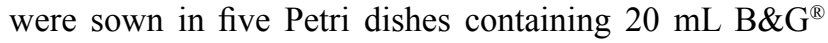
(B\&G flores company) culture medium with full and half strength, supplemented with $58.4 \mathrm{mM}$ sucrose, $\mathrm{pH} 5.6 \pm$ 0.1 , and solidified with $10.0 \mathrm{~g} \mathrm{~L}^{-1}$ agar (HiMedia ${ }^{\circledR}$ ). Cultures were maintained under $16 \mathrm{~h}$ photoperiod, with irradiance of $36 \mathrm{mmol} \mathrm{m}^{-2} \mathrm{~s}^{-1}$ provided by two fluorescent tubes (Luz do Dia Especial, $20 \mathrm{~W}$, Osram, Brazil), and temperature of $27 \pm 2{ }^{\circ} \mathrm{C}$, in a growth room. After 60 days of sowing, seed germination data were obtained using a light optical microscope to count green and albino protocorms in three areas $(2.0 \mathrm{~cm}$ in diameter) in each Petri dish.

The protocorms growth observation was carried out after germination phase. So, green and albino protocorms coming from geitonogamic pollination were put into flasks $\left(250 \mathrm{~mL}\right.$ ) with $50 \mathrm{~mL}$ of each $\mathrm{B} \& \mathrm{G}^{\circledR}$ medium (full and half strength) totalizing four treatments, each one with five flasks (replicates), containing 10 protocorms. After 120 days, pigments extraction and measurement of chlorophyll-a, chlorophyll-b and total carotenoids were performed (Soni et al., 2018). Samples of orchid seedlings (0.5 g), in triplicate, were taken and carefully crushed by adding $5 \mathrm{~mL}$ of the solvent methanol in pestle mortar and transferred in test tubes ( $25 \mathrm{~mL}$ capacity) and covered using aluminum foil. Later all samples were centrifuged for 10,000 rpm for 15 minutes. Further supernatants were separated and 0.5 $\mathrm{mL}$ supernatants from each sample were taken in fresh test tubes and $5 \mathrm{~mL}$ methanol was added. Later each sample 
solution was analyzed for their Chlorophyll- $a$ (652.4 and $665.2 \mathrm{~nm})$, Chlorophyll- $b$ (652.4 and $665.2 \mathrm{~nm})$ and carotenoid $(470 \mathrm{~nm})$ using a spectrophotometer, and each pigment concentration was calculated using the respective formula $\left(\mathrm{Ch} a=16.72 \mathrm{~A}_{665.2}-9.16 \mathrm{~A}_{652.4} ; \mathrm{Ch} b\right.$ $=34.09 \mathrm{~A}_{652.4}-15.28 \mathrm{~A}_{665.2} ; \mathrm{Car}=\left(1000 \mathrm{~A}_{470}-1.63 \mathrm{Cha}\right.$ - 104.96Chb)/221 (Soni et al., 2018). After that, values obtained $\left(\mu \mathrm{g} \mathrm{mL}^{-1}\right)$ were converted to $\mathrm{mg} \mathrm{g} \mathrm{FW}^{-1}$.

All experiments were arranged using a completely randomized design, with five replicates per treatment. Percentage data were arcsine transformed prior to statistical analysis and then submitted to an analysis of variance (ANOVA) and a means comparison by the Tukey test at 5\% significance $(p<0.05)$, using the statistical software SISVAR 4.3 (Ferreira, 2019). The expected and observed genetic ratios for green and albino phenotype of Cycnoches haagii seedlings fertilized by self-pollination were tested using the chi-square $\left(\mathrm{X}^{2}\right)$ test (Sokal and Rohlf, 1995). All listed experiments were repeated twice.

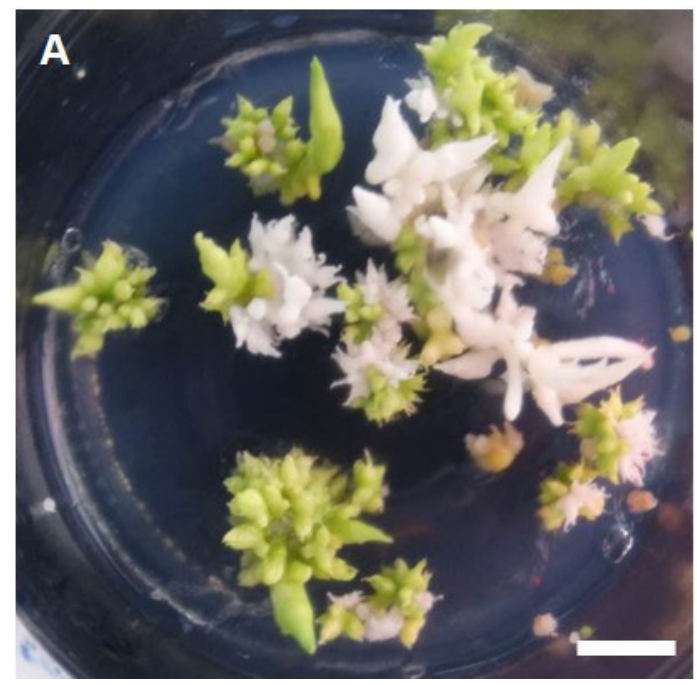

\section{Results and Discussion}

No statistical difference was found in the germination percentage of seeds originated from both pollination processes, independent of the medium strength, resulting in mean values around $90.0 \%$. This germination rate was higher than the $78.4 \%$ obtained by Torrezan et al. (2018), also under asymbiotic conditions in B\&G medium, but using seeds resulted from natural pollination, resulting in protocorms and seedlings with normal phenotype or green phenotype. Differently, here we were investigating the $C$. haagii germination using seeds obtained by self and cross-pollination processes. The initial visual aspect of protocorms came from self-pollinated seeds showed two different phenotype patterns, progressing to different seedlings phenotype (Figure 1A). In this case, seeds from self-pollination originated $25 \%$ and $75 \%$ of seedlings with albino and green phenotypes, respectively, whereas seeds from cross-pollination resulted in $100 \%$ of seedlings with green phenotype (Figure 1B).

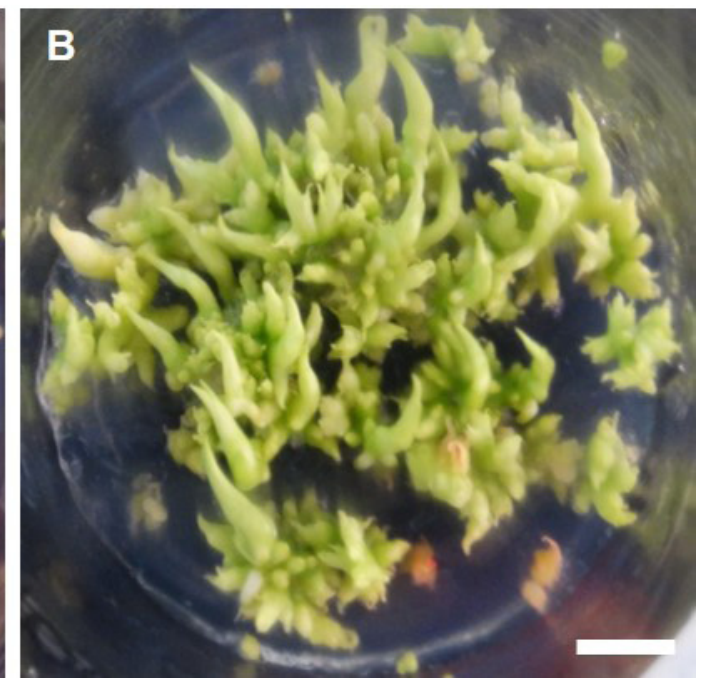

Figure 1. Seedlings of Cycnoches haagii resulted from seeds obtained by (A) geitonogamy and (B) xenogamy, and germinated on $B \& G^{\circledR}$ medium under in vitro asymbiotic conditions. Bar $=1 \mathrm{~cm}$.

This behavior indicates that some level of genetic barrier is present in the self-pollination when compared to crosspollination to this species. A similar research was carried out by Paiva Neto et al. (2015) with Bletia catenulata, another native orchid species found at Brazilian Cerrado, but they did not register phenotypic differences in the seedlings regardless of the type of pollination performed.

Most studies conducted to investigate the inheritance of albinism have found that it is a recessive trait ruled by one or two genes with two alleles, albinism being recessive (Kumari et al., 2009). In this context, albino plants are also commonly used for studying chloroplast development and function. Previous studies show that albino plants derived from mutation together with their green counterparts are ideal genetic materials for identifying mutated genes involved in the chloroplast biogenesis and development (Hung et al., 2021).
Because many mutants that are defective in an envelope membrane protein exhibit an embryo lethal phenotype (Hormann et al., 2004, Baldwin et al., 2005, Patel et al., 2008, Hsu et al., 2010, Tada et al., 2014), the number of albino mutants that can be used for investigations is limited, showing the importance of discovering new albino individuals.

Although visually imperceptible, the pigments analysis showed that even the albino seedlings presented chlorophylls and carotenoids, however in significantly minor concentrations, with only $14.4 \%$ and $16.1 \%$ respectively, in relation to green seedlings (Table 1). Medium strength yet altered the pigment levels in the seedlings tissues, and higher chlorophyll and carotenoid presence were found in seedlings cultivated on medium with full strength (Table 1). 
Table 1. Content of $a$ and $b$ chlorophylls, and total carotenoids of albino and green seedlings of Cycnoches haagii obtained from geitonogamic seeds germinated on $B \& G^{\circledR}$ medium with full or half strength and under in vitro asymbiotic conditions.

\begin{tabular}{|c|c|c|c|c|}
\hline \multirow{2}{*}{ Phenotype } & \multirow{2}{*}{ Medium Strength } & \multicolumn{2}{|c|}{ Chlorophyll (mg g FW' FW $\left.^{-1}\right)$} & \multirow{2}{*}{ Carotenoids (mg g FW-1) } \\
\hline & & $\mathbf{a}$ & $\mathbf{b}$ & \\
\hline Albino & half & $0.071 \mathrm{~d}$ & $0.058 \mathrm{~d}$ & $0.131 \mathrm{~d}$ \\
\hline Albino & full & $0.231 \mathrm{c}$ & $0.304 \mathrm{c}$ & $0.254 \mathrm{c}$ \\
\hline Green & half & $0.923 \mathrm{~b}$ & $0.528 \mathrm{~b}$ & $1.019 b$ \\
\hline Green & full & $1.475 \mathrm{a}$ & $1.170 \mathrm{a}$ & $2.075 \mathrm{a}$ \\
\hline
\end{tabular}

Means followed by the same letter in the same column indicate no statistically significant difference, according to Tukey's test at a probability of $5 \%$.

Here we found that albino seedlings have limiting pigments synthesis. In a comparative study on green and albino plants, Abadie et al. (2006) found that chlorophyll content was significantly lower for albino $\left(1.9 \pm 5 \times 10^{-2} \mu \mathrm{g}\right.$ $\mathrm{mg}$ fresh weight $\left.{ }^{-1}\right)$ compared to green $(2.97 \pm 0.56 \mu \mathrm{g} \mathrm{mg}$ fresh weight ${ }^{-1}$ ) individuals. Yao and Cohen (2000) analyzed the pigment contents in albinos and green progenies of Zantedeschia using High Pressure Liquid Chromatography (HPLC) and found the levels of violaxanthin, lutein, chlorophyll $a$, chlorophyll $b$ and $\beta$-carotene were reduced to $1 \%-6 \%$ compared with the levels in green leaf tissue. According to Silva et al. (2020), albino plants are characterized by the white/pale color of normally green organs due to partial or complete loss of photosynthetic pigments. Here we have only partial loss of the chlorophyll synthesis capacity.

Single-gene control of albinism is not uncommon in the plant kingdom. Shull (1915) described similar genetic systems that control 2 types of albinism in maize - one producing pure white seedlings and the other resulting in yellowish white (chlorina) seedlings; both types of albinism are recessive, simply inherited, and controlled by a single diallelic locus. However, some species of the genus Cycnoches were described with the frequent number of chromosomes $2 \mathrm{n}=2 \mathrm{x}=68(\mathrm{n}=34)$ (Félix and Guerra, 2000), and although there is no information about $C$. haagii. the possible occurrence of polyploidy in this specie could explain, in parts, this phenomenon, but it also needs confirmation. In addition, the hypothesis of albinism being controlled in $C$. haagii by a gene with two-allele is plausible when under self-pollination. Expected and observed ratio of green and albino seedlings obtained by self-pollination (Table 2), confirm this, as also proposed by (Gettys and Wofford, 2007).

But one question remains unclear: why albinism was absent in the crossing-progeny, since the parents are expected to be heterozygous for this gene? One possible reason is that some mechanism prevents the albinism manifestation in the cross-pollination.

Recessive lethal alleles are routinely maintained in heterozygous individuals within populations and typically have no deleterious effect on the health of heterozygous plants; however, it is unclear whether lethal recessive alleles provide any hidden benefit to populations (Gettys and Wofford, 2007).

It is important to emphasize that pollen origin directly influences in the pigments synthesis capacity of the seedlings, and that geitonogamic pollination of the orchid C. haagii results in $25 \%$ of albino descendants (Table 2).

These results will be useful in future researches with homozygous albino plants to help us understand the contribution of functional chloroplasts and mycorrhizal fungi for orchid growth and development, using albino plants as model.

Table 2. Expected and observed ratio for albino and green phenotypes of Cycnoches haagii seedlings fertilized by selfpollination, according to the hypothesis of inheritance proposed for this trait.

\begin{tabular}{|c|c|c|c|c|}
\hline Phenotype & Expected ratio & Observed ratio & Hypothesis & $\mathbf{X}^{\mathbf{2}}$ \\
\hline Green & 1509.75 & 1501 & 3 & $0.2028^{\mathrm{ns}}$ \\
\hline Albino & 503.25 & 512 & 1 & $0.6524^{\mathrm{ns}}$ \\
\hline
\end{tabular}

$\mathrm{X}^{2}$ : chi-squar test $(\mathrm{p}<0.05)$; ns: not-significant $(t$-test $\mathrm{p}<0.05)$. 


\section{Conclusions}

Geitonogamic and xenogamic pollinations resulted in C. haagii viable seeds with high germination percentage $(90 \%)$ under in vitro conditions. However, geitonogamic pollination should be avoided at conservation programs of this orchid species as it originates albino seedlings. Nonetheless, it showed a very interesting system to obtain seedlings with albino phenotype, an interesting plant material to future investigations.

\section{Author Contribution}

VBPN: Species collection and cultivation, pollination, experimental supervision, writing, editing, reviewing. MAT: Investigation, methodology, data collect. MAVS: Investigation, methodology, data collect. DRCP: Methodology, experimental supervision, writing, editing. JCB: Methodology, original draft, writing. MCRZB: Statistical analysis, writing.

\section{Acknowledgments}

The authors acknowledge the Conselho Nacional de Desenvolvimento Científico e Tecnológico (CNPq, Process number 503472/2009-3) and also the Fundação de Apoio ao Desenvolvimento do Ensino, Ciencia e Tecnologia do Estado de Mato Grosso do Sul (FUNDECT, Process No. 23/200.233/2010) for their financial support for the project.

\section{References}

ABADIE, J.C.; PUTTSEPP, U.; GEBAUER, G.; FACCIO, A.; BONFANTE, P.; SELOSSE, M.A. Cephalanthera longifolia (Neottieae, Orchidaceae) is mixotrophic: a comparative study between green and non photosynthetic individuals. Canadian Journal of Botany, v.84, p.14621477, 2006. https://doi.org/10.1139/B6-101.

BALDWIN, A.; WARDLE, A.; PATEL, R.; DUDLEY, P.; PARK, S.K.; TWELL, D.; INOUE, K.; JARVIS, P. A molecular-genetic study of the Arabidopsis Toc75 gene family. Plant Physiology, v.138, p.715-733, 2005. https:// doi.org/10.1104/pp.105.063289.

BALILASHAKI, K.; GANTAIT, S.; NADERI, R; VAHEDI, M. Capsule formation and asymbiotic seed germination in some hybrids of Phalaenopsis, influenced by pollination season and capsule maturity. Physiology and Molecular Biology of Plants, v.21, n.3, p.341-347, 2015. https://doi.org/10.1007/s12298-015-0309-z

BARROS, F.; HALL, C.F.; PAIVA NETO, V.B.; BATISTA, J.A.N. Checklist das Orchidaceae do Estado de Mato Grosso do Sul, Brasil. Iheringia Série Botânica, v.73, p.287-296, 2018. https://doi.org/10.21826/2446-8231201873s287.
BARROS, F.; VINHOS, F.; RODRIGUES, V.T.; BARBERENA, F.F.V.A.; FRAGA, C.N.; PESSOA, E.M.; FORSTER, W.; MENINI NETO, L.; FURTADO, S.G.; NARDY, C.; AZEVEDO, C.O.; GUIMARÃES, L.R.S. 2015. Orchidaceae. Lista de espécies da flora do Brasil. Jardim Botânico do Rio de Janeiro. Available at: <http:// floradobrasil.jbrj.gov.br/jabot/floradobrasil/FB37473>. Accessed on: May $1^{\text {st }} 2018$.

BEZERRA, G.A.; GABRIEL, A.V.M.D.; MARIANO, E.D.; CARDOSO, J.C. In vitro culture and greenhouse acclimatization of Oncidium varicosum (Orchidaceae) with microorganisms isolated from its roots. Ornamental Horticulture, v.25, p.407-416, 2019. https://doi. org/10.1590/2447-536x.v25i4.2046

CATLING, P.M.; CATLING, V.R. A synopsis of breeding systems and pollination in North American orchids. Lindleyana, v.6, n.3, p.187-210, 1991.

CHASE, M.W.; CAMERON, K.M.; FREUDENSTEIN, J.V.; PRIDGEON, A.M.; SALAZAR, G.; BERG, C.; SCHUITEMAN, A. An updated classification of Orchidaceae. Botanical Journal of the Linnean Society, v.177, n.2, p.151174, 2015. https://doi.org/10.1111/boj.12234

FÉLIX, L.P.; GUERRA, M.Cytogenetics and cytotaxonomy of some Brazilian species of Cymbidioid orchids. Genetics and Molecular Biology, v.23, n.4, p.957-978, 2000. https:// doi.org/10.1590/S1415-47572000000400041

FERREIRA, D.F. Sisvar: A computer analysis system to fixed effects split plot type designs. Revista Brasileira de Biometria, v.37, n.4, p.529-535, 2019. https://doi. org/10.28951/rbb.v37i4.450

GETTYS, L.A.; WOFFORD, D.S. Genetic control of albinism in pickerelweed (Pontederia cordatia L.). Journal of Heredity, v.98, n.4, p.356-359, 2007. https:// doi.org/10.1093/jhered/esm046

HORMANN, F.; KÜCHLER, M.; SVESHNIKOV, D.; OPPERMANN, U.; LI, Y.; SOLL, J. Tic32, an essential component in chloroplast biogenesis. Journal of Biological Chemistry, v.279, n.33, p.34756-34762, 2004. https:// dx.doi.org/10.1074\%2Fjbc.A402817200

HSU, S.C.; BELMONTE, M.F.; HARADA, J.J.; INOUE, K. Indispensable roles of plastids in Arabidopsis thaliana embryogenesis. Current Genomics, v.11, v.5, p.338-349, 2010. https://doi.org/10.2174/138920210791616716.

HUANG, H.; ZI, X-M.; LIN, H.; GAO, J-Y. Host-specificity of symbiotic mycorrhizal fungi for enhancing seed germination, protocorm formation and seedling development of over-collected medicinal orchid, Dendrobium devonianum. Journal of Microbiology, v.56, n.1, p.42-48, 2018. https:// doi.org/10.1007/s12275-018-7225-1 
HUNG, C.-Y.; ZHANG, J.; BHATTACHARYA, C.; LI, H.; KITTUR, F.S.; OLDHAM, C.E.; WEI, X.; BURKEY, K.O.; CHEN, J.; XIE, J. Transformation of long-lived albino Epipremnum aureum 'Golden Pothos' and restoring chloroplast development. Frontiers in Plant Science, v.12, 2021. http://dx.doi.org/10.3389/fpls.2021.647507

HUNHOFF, V.L.; LAGE, L.A.; PALÚ, E. G.; KRAUSE, W.; SILVA, C.A. Nutritional requirements for germination and in vitro development of three Orchidaceceae species in the southern Brazilian Amazon. Ornamental Horticulture, v.24, n.2, p.87-94, 2018. http://dx.doi.org/10.14295/ oh.v24i2.1130

JOHNSON, T.R.; KANE, M.E. Effects of temperature and light on germination and early seedling development of the pine pink orchid (Bletia purpurea). Plant Species Biology, v.27, n.2, p.174-179, 2012. https://doi.org/10.1111/j.14421984.2011.00347.x

KUMARI, M.; CLARKE, H.J.; SMALL, I.; SIDDIQUE, K.H.M. Albinism in plants: a major bottleneck in wide hybridization, androgenesis and doubled haploid culture. Critical Reviews in Plant Sciences, v.28, n.6, p.393-409, 2009. https://doi.org/10.1080/07352680903133252

MERCADO, S.A.S.; CONTRERAS, N.A.V. Asymbiotic seed germination and in vitro propagation of Cattleya trianae Linden \& Reichb. f. (Orchidaceae). Acta Agronómica, v.66, n.4, p 544-548, 2017. https://doi. org/10.15446/acag.v66n4.63597

MICKELIUNAS, L.; PANSARIN, E.R.; SAZIMA, M. Biologia floral, melitofilia e influência de besouros Curculionidae no sucesso reprodutivo de Grobya amherstiae Lindl. (Orchidaceae: Cyrtopodiinae). Revista Brasileira de Botânica, v.29, n.2, p.251-258, 2006. https:// doi.org/10.1590/S0100-84042006000200006

PAIVA NETO, V.B.; MEZONI, A.P.; BARROS, F.; PADILHA, D.R.C.; BORGES, M.C.R.Z. The Bletia catenulata ornamental orchid is self-compatible but pollinator-dependent for reproduction. Pesquisa Agropecuária Tropical, v.45, n.4, p.473-479, 2015. https://doi.org/10.1590/1983-40632015v4538410

PATEL, R.; HSU, S.C.; BEDARD, J.; INOUE, K.; JARVIS, P. The Omp85-related chloroplast outer envelope protein OEP80 is essential for viability in Arabidopsis. Plant Physiology, v.148, n.1, p.235-245, 2008. https://doi. org/10.1104/pp.108.122754

RASMUSSEN, H.N.; DIXON, K.W.; JERSÁKOVÁ, J.; TĚŠITELOVÁ, T. Germination and seedling establishment in orchids: a complex of requirements. Annals of Botany, v.116, n.3, p.391-402, 2015. https://doi.org/10.1093/aob/mcv087.

SHULL, G.H. Albinism in maize. Botanical Gazette, v.60, n.4, p.324-325, 1915 .
SILVA, C.D.S.; ARAUJO, L.G.D.; SOUSA, K.C.I.; SILVA, D.M.; SIBOV, S.T.; FARIA, P.R. Germinação e desenvolvimento in vitro de orquídea epífita do Cerrado. Ornamental Horticulturae, v.23, n.1, p.96-100, 2017. http://dx.doi.org/10.14295/oh.v23i1.923

SILVA, L.A.S.; SAMPAIO, V.F.; BARBOSA, L.C.S.; MACHADO, M.; FLORES-BORGES, D.N.A.; SALES, J.F.; OLIVEIRA, D.C.; MAYER, J.L.S.; KUSTER, V.C.; ROCHA, D.I. Albinism in plants - far beyond the loss of chlorophyll: Structural and physiological aspects of wildtype and albino royal poinciana (Delonix regia) seedlings. Plant Biology, v.22, n.5, p.761-768, 2020. https://doi. org/10.1111/plb.13146

SMIDT, E.C.; SILVA-PEREIRA, V.; BORBA, E.L. Reproductive biology of two Cattleya (Orchidaceae) species endemic to North-eastern Brazil. Plant Species Biology, v.21, n.2, p.85-91, 2006. https://doi.org/10.1111/ j.1442-1984.2006.00154.x

SOKAL, R.R.; ROHLF, F.J. Biometry: the principles and practice of statistics in biological research. 3rd edition. New York: W.H. Freeman and Co., 1995. 887p.

SONI, D.K.; SHAHI, S.K.; KHANDEL, P.; MAHOBIYA, D.; SINGH, R.; YADAW, R.K.; KANWAR, L. Extraction and estimation of chlorophylls from epiphytic orchids and their antioxidants scavenging activity analysis. Plant Archives, v.18, n.2, p.2448-2452, 2018.

STEWART, S.S.; KANE, M.E. Symbiotic seed germination of Habenaria macroceratitis (Orchidaceae), a rare Florida terrestrial orchid. Plant Cell Tissues and Organ Culture, v.86, p.159-167, 2006. https://doi.org/10.1007/s11240006-9104-4

TADA, A.; ADACHI, F.; KAKIZAKI, T.; INABA, T. Production of viable seeds from the seedling lethal mutant ppi2-2 lacking the atToc159 chloroplast protein import receptor using plastic containers, and characterization of the homozygous mutant progeny. Frontiers in Plant Science, v.5, n.243, p.1-7, 2014. https://doi.org/10.3389/ fpls.2014.00243

TORREZAN, M.A.; SILVA, M.A.V.; PAIVA NETO, V.B.; PADILHA, D.R.C.; SANTOS, A.J.S. Precocious flowering of plants resulting from in vitro germination of Cycnoches haagii seeds on mycorrhizal fungi presence. Pesquisa Agropecuária Tropical, v.48, n.4, p.468-475, 2018. https://doi.org/10.1590/1983-40632018v4853396

UTAMI, E.S.W.; HARIYANTO, S. In vitro seed germination and seedling development of a rare indonesian native orchid Phalaenopsis amboinensis J.J.Sm. Scientifica, v.2019, p.16, 2019. https://doi.org/10.1155/2019/8105138 
WU, K.; ZENG, S.; LIN, D.; SILVA, J.A.T.; BU, Z.;
ZHANG, J.; DUAN, J. (2014). In vitro propagation and reintroduction of the endangered Renantheraim schootiana Rolfe. PLoS ONE, v.9, n.10, e110033. https://doi. org/10.1371/journal.pone.0110033
YAO, J.L.; COHEN, D. Multiple gene control of plastomegenome incompatibility and plastid DNA inheritance in interspecific hybrids of Zantedeschia. Theorical and Applied Genetics, v.101, p.400-406, 2000. https://doi. org/10.1007/s001220051496 